service to the world if they were allowed the leisure and peace of mind to prosecute their researches unhampered by the care and training of research collaborators. The methods of the solitary philosopher, the methods of Davy and Faraday, can scarcely be excelled. Research in the academic sense has become a fashion; it will soon become a trade and then farewell to the hopes that Great Britain will again produce the few particular men who, in a flash of genius, have turned discovery into invention and invention into industry. Scotland has given to the world such pioneers, and is not lacking in the qualities which are needful.

\section{Reduction of Working Hours in Industry}

THE uncompromising attitude of certain sections of British industry to proposals for the reduction of working hours might be regarded with some amusement but for the serious results which it is likely to precipitate. The portentous arguments set forth, for example, by the National Federation of Employers Organisations against the forty-four hour week recapitulate in unmistakably the same accents those advanced with equal plausibility in previous generations against Factory Acts, the abolition of child labour and the limitation by law of the hours of work by women and children. There are, however, important firms such as Imperial Chemical Industries, Ltd., in its Billingham Works, and Boots Pure Drug Co., at Nottingham, which have had the courage and wisdom to determine the possibilities of the forty-hour or five-day week by direct experiment. The experiment carried out at Nottingham is of the greater interest in that its results have been made generally available in an important report by Sir Richard Redmayne, who was nominated by the Ministry of Labour, at the firm's request, to conduct an exhaustive inquiry as to whether the permanent adoption of the five-day week in all its works is possible ("A Review of the Experimental Working of the Five Days Week by Boots Pure Drug Company at Nottingham." By Sir Richard A. S. Redmayne. Pp. 70. Nottingham : Boots Pure Drug Co., 1934. 1s.). The publication of the full details of this investigation in itself constitutes a noteworthy break with the tradition of secrecy which has hampered the pooling of experience in matters of industrial safety, hygiene, labour policy, etc.

Sir Richard Redmayne concludes that the working of the five days working week inaugurated on April 30, 1934, and terminating on September 29, has proved an unqualified success both from the business point of view and from that of the employees. $\mathrm{He}$ is satisfied that the cost in the aggregate has not been enhanced and the efficiency of the employees has been increased. Marked improvements in health, contentment, regularity of attendance at work and diminution of absenteeism have been observed since the start of the experiment, and the employees themselves would view with dismay any return to the five and a half day week. Had the working hours per week not been reduced, it would have been necessary to discharge a number of workers, and from this point of view alone the experiment has already been of real benefit to the community itself. Sir Richard Redmayne is satisfied that equally satisfactory results would be obtained if the experiment was continued over the winter months. It is, of course, difficult to say how far the experiment can be applied to other concerns with equal prospects of success. The intimate relation of production and distribution in this particular concern has probably contributed largely to its success, but Sir Richard Redmayne considers that there are many works at which the five day week might be tried with equal prospects of success. Messrs. Boots have set an example in scientific experiment on a most important social-industrial question, and scientific workers should not be slow in pointing out to the community the possibility of obtaining similar decisions in these matters in other industries or concerns.

\section{Rare Books on Magic}

AN exhibition of old and rare works dealing with magic, witchcraft, legerdemain and kindred subjects was opened on December 6 and was on view until December 14 at the University of London Council of Psychical Investigation, 13D Roland Gardens, South Kensington, London, S.W.7. Five hundred items had been selected for exhibition out of the 12,000 volumes collected by Mr. Harry Price, the honorary secretary of the Council, forming what is probably the largest and most important assemblage of printed works relating to occult subjects available for the student. The books exhibited ranged in date from about 1490 to the present day, though, curiously enough, the "Malleus Maleficarum" (1488), the first printed work on witcheraft, and the Bible of the witch finder, was not represented by a copy earlier than 1576. Works dealing with magic and the witch, ghosts and spiritual manifestations generally, of the sixteenth, seventeenth and early eighteenth centuries are becoming increasingly rare and expensive, and many of them in a few years' time will be unobtainable. A specialised library of the size of that of the Council for Psychical Investigation is, therefore, of great importance for the psychologist and the social historian. In looking through any extensive range of books such as this, it is significant to note how slow has been the growth in appreciation of the nature of evidence when any element of the supernatural has been implicated in an investigation. Although early works, such as Lavater's "Ghostes and Spirites Walking by nyghte ..." (1572) and Scot's "The Discoverie of Witchcraft" are thoroughly sceptical, it was not until 1668, in the work of the Rev. Joseph Glanville, fellow of the Royal Society and virtually the father of psychical research, that anything in the nature of a systematic setting out of evidence was attempted.

THE recent haunting at Saragossa, in which voices in a chimney have been explained as due to the "unconscious ventriloquism" of a serving maidan explanation almost as mysterious as the phenomena it explains-adds interest to the accounts in this 